\title{
Evaluation of six tomato (Lycopersicum esculentum) varieties for industrial tomato sauce preparation'
}

\author{
Horacio Ramírez, ${ }^{,}$Teresita Rodríguez ${ }^{s}$ and Irvis $Y$. Pagán 4
}

\begin{abstract}
This study is concerned primarily with evaluating six processing tomato varieties grown in Santa Isabel by the Land Authority of Puerto Rico: Zenith (Hyb.), Hybrid 337, Ventura (o.p.), Peto-98 (o.p.) and two Nema varieties (Nema-1, Nema-2). For each variety, the fruits were comminuted, pulped and concentrated. The tomato concentrate obtained was used for sauce preparation. The six varieties were all found to be suitable for industrial elaboration of tomato sauce. Each of the sauces formulated had the required characteristics of a good commercial tomato sauce.

RESUMEN

Evaluación de seis variedades de tomate (Lycopersicum esculentum) para la preparación industrial de salsa de tomate.

Se evaluaron seis variedades de tomate para determinar si eran aptas para usarse en formulaciones industriales de salsas de tomate. Las variedades fueron Zenith (hyb.), Hybrid 337, Ventura (o.p.), Peto-98 (0.p.) y dos variedades Nema (Nema-1, Nema 2).

Se analizaron características físicas, químicas y micbrobiológicas después de dos semanas de elaboración. Los resultados de estos análisis cumplen con el Grado A para salsas de fomate establecido por el Departamento de Agricultura Federal. Basados en estos resultados, se puede concluir que todas las variedades evaluadas pueden usarse en formulaciones industriales para la elaboración de salsa de tomate de buena calidad.
\end{abstract}

\section{INTRODUCTION}

Tomato sauce is the concentrated product prepared from the liquid extracted from mature sound whole tomatoes, the sound residue from preparing such tomatoes for canning, the residue from partial extraction of juice, or any combination of these ingredients, to which salt, spices, one or more nutritive sweeteners, a vinegar or vinegars, onions or other vegetable flavoring ingredients may be added $(1,3)$. This product is described as an acid food (5), which is defined as one having an equilibrium $\mathrm{pH}$ of less than 4.6 .

'Manuscript submitted to Editorial Board 8 August 1989.

${ }^{2}$ Consultant engineer, Land Authority of Puerto Rico.

${ }^{3}$ Research Associate, Laboratory of Food Technology

'Laboratory Technician, Laboratory of food Technology.

The authors thank Mr. Fred Fernández for reading and offering helpful suggestions for improving this manuscript. 
In 1983, the United States led tomato growers worldwide (10). Statistics from the Bureau of the Census indicated that 77,364 cases of tomato sauce with a value of $\$ 803.6$ million were packed in the United States in 1982 (1), thus demonstrating the economic importance of tomato production and processing.

Since in Puerto Rican cuisine tomato sauce is an essential ingredient, it is produced locally by various food processors. Tomato sauce is locally produced from tomato paste or puree which are imported from different countries. This paste or puree, in turn, is obtained by concentrating tomato juice (6). Local farmers are trying to establish tomato varieties suitable for processing, thus adding a new dimension to tomato production in Puerto Rico.

This study is concerned primarily with evaluating six processing tomato varieties grown in Santa Isabel by the Land Authority of Puerto Rico: Zenith (hyb.), Hybrid 337, Ventura (o.p.), Peto-98 (o.p.) and two Nema varietie: Nema-1 and Nema-2. These varieties were first fieldevaluated by the Land Authority for characteristics such as high Brix, high yield and fruit firmness. We proceeded to evaluate these six varieties for good quality tomato sauce.

\section{MATERIALS AND METHODS}

All six tomato varieties were harvested by hand, packed in cardboard boxes, brought to the Food Technology Laboratory and stored for a maximum of eight days at $45^{\circ} \mathrm{F}$. After storage, fruits were weighed, washed and sorted by hand to remove broken, diseased, moldy or otherwise objectionable tomatoes. The selected fruits were washed again and comminuted in a Fitzpatrick Model-D Comminuting Machine (Chicago, Illinois) ${ }^{6}$ with $1 / 4$ inch diameter sieve. The comminuted product was heated at a temperature of $180^{\circ} \mathrm{F}\left(82^{\circ} \mathrm{C}\right)$ for 15 seconds in a tubular pasteurizer (Votator, Louisville, Kentucky). The latter step inactivated pectinolytic enzymes inherent to the tomato that would otherwise cause the breakdown of the pectinous substances in the product within a very short time $(6,7,9)$. The skins and seeds were screened out with a Langsenkap Model 1448 pulper (Indianapolis, Indiana) with a 0.045 inch diameter sieve. The product was then passed through a finisher (Langsenkap Model 1859, Indianapolis, Indiana) with a 0.033 inch diameter sieve.

Concentration of the product was performed in a vacuum evaporator (Roto-Vak, Buflovak Equipment Division-Blaw-Knox Company, Buffalo,

\footnotetext{
"Trade names in this publication are used only to provide specific information. Mention of a trade name does not constitute a warranty of equipment or materials by the Agricultural Experiment Station of the University of Puerto Rico, nor is this mention a statement of preference over other equipment or materials.
} 
N.Y.) operated at a temperature of $120^{\circ} \mathrm{F}\left(49^{\circ} \mathrm{C}\right)$ under 20 psi vacuum. Samples were concentrated to 7.5 to $10.0^{\circ}$ Brix depending upon the variety. The tomato concentrate was then transferred to a 50 -gal. stainless steel tank with continuous agitation for formulation purposes. The formula:

$\begin{array}{lr}\text { Tomato concentrate } & 95.87 \% \\ \text { Modified corn starch (COLFLO-67) } & 2.54 \% \\ \text { Salt } & 1.00 \% \\ \text { Onion } & 0.50 \% \\ \text { Garlic } & 0.05 \% \\ \text { Cayenne red pepper } & 0.04 \%\end{array}$

The formulated batch was analyzed for percentage soluble solids ( ${ }^{\circ}$ Brix) by using an Abbe refractometer (AO Mark II Digital Refractometer, Buffalo, N.Y.) according to Herschdoerfer (8). Determination of $\mathrm{pH}$ values was performed with a Beckman pHI 71 meter (Fullerton, California).

We commercially sterilized the tomato sauce at a temperature of $200^{\circ}$ $\mathrm{F}\left(93^{\circ} \mathrm{C}\right)$ for 1 minute in a tubular pasteurizer (Votator, Louisville, Kentucky). Tin cans size $211 \times 300$ were filled hot with the product at a temperature of no less than $190^{\circ} \mathrm{F}\left(88^{\circ} \mathrm{C}\right)$ and sealed. The cans were then inverted and held thus for three minutes to sterilize the lids. They were cooled to $100^{\circ} \mathrm{F}\left(38^{\circ} \mathrm{C}\right)$ in a spin cooler before being cased and stored at room temperature.

After 2-week storage, 12 samples were taken for physical (color and viscosity), chemical ( ${ }^{\circ}$ Brix and $\mathrm{pH}$ ) and microbiological (total plate count) analyses. Color measurements were performed in a Lab Scan Spectocolorimeter (Hunterlab, Reston, Virginia), since previous works have shown that the $L, a, b$ system is the most suitable for assessing color (2, 4). Viscosity of the tomato sauce was determined with a Bostwick consistometer (Fairfax, Virginia) as the average distance traveled by the sample in 30 seconds at room temperature. For microbiological analyses, Plate Count Agar (PCA; Difco Laboratories, Detroit, Michigan) poured plates incubated at $90^{\circ} \mathrm{F}\left(30^{\circ} \mathrm{C}\right)$ for 25 hours were used to quantify bacterial populations.

Figure 1 represents a flow diagram illustrating all processing steps in tomato sauce elaboration.

\section{RESULTS AND DISCUSSION}

The following tabulation summarizes the percentage soluble solids ( ${ }^{\circ} \mathrm{Brix}$ ) and $\mathrm{pH}$ values of the six tomato varieties. The highest percentage of soluble solids is seen in Nema-2, whereas the lowest figure is seen in Peto-98 (o.p.). 


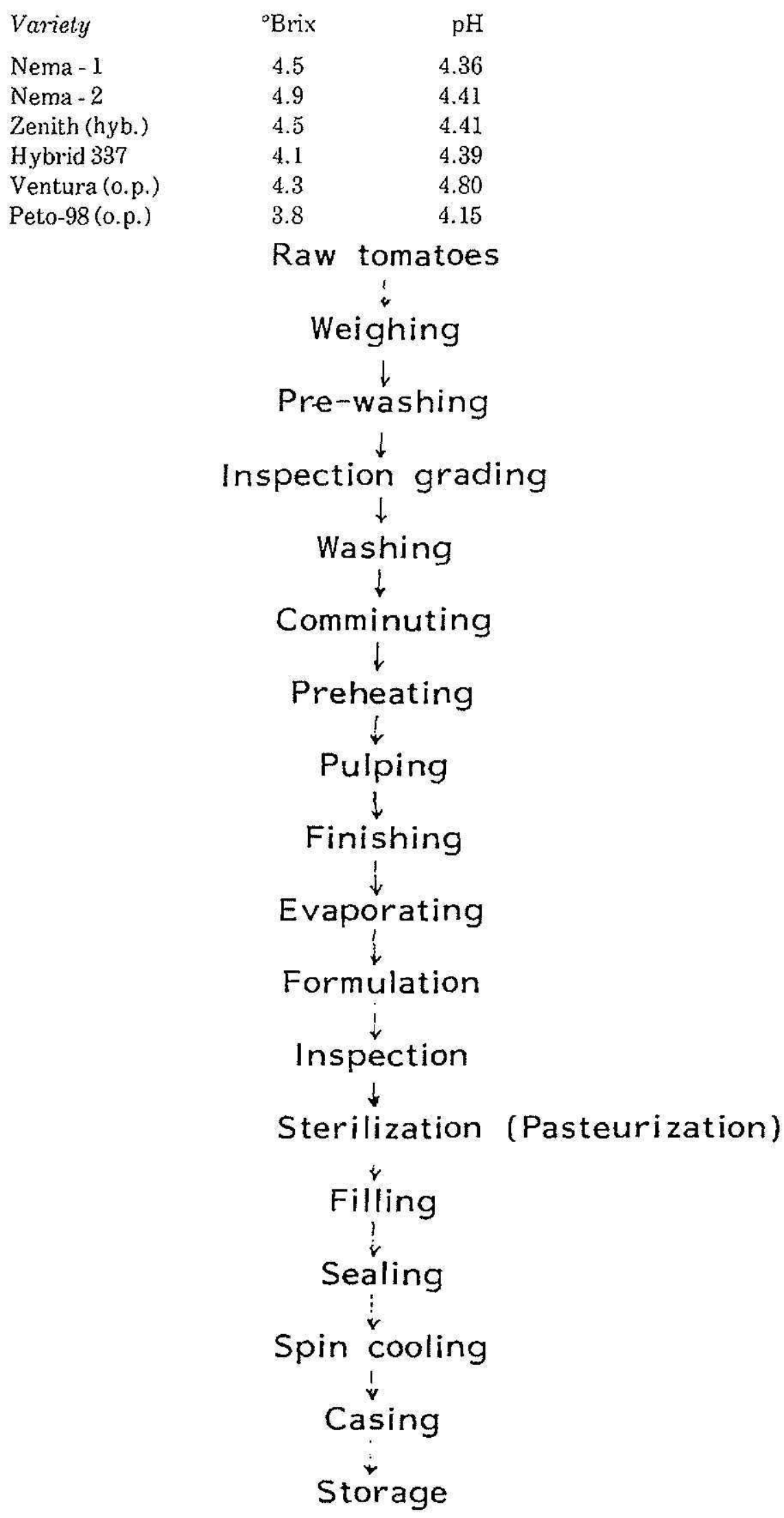

FIG. 1: Flow diagram of tomato sauce processing. 
The mass balance per tomato variety appears in Table 1 . In some varieties, the discarded raw material is high (Hybrid 337 and Ventura). As follows, this was not due to varieties' deficiencies, but to a greater storage time, since the percentage of spoiled fruits increases with storage. Tomatoes should be processed within 24 hours after harvesting $(2,9)$.

\begin{tabular}{lcc} 
& \multicolumn{2}{c}{ Time } \\
Variety & Hours & Days \\
Nema- 1 & 24 & - \\
Nema-2 & 48 & - \\
Zenith (hyb.) & 72 & - \\
Hybrid 337 & - & 7 \\
Ventura (o.p.) & - & 8 \\
Peto 98 (o.p.) & 24 & -
\end{tabular}

It is also important to point out from table 1 that the yields of finished tomato pulp ranges between $84.5 \%$ and $88.3 \%$, which can be considered very good. The amount of tomato concentrate (lbs.) obtained from each variety is sufficient, although some equipment-related technical problems produced losses in two of them (Hybrid 337 and Ventura). The soluble solids obtained for each tomato concentrate were considered good enough for formulating purposes.

The physical and chemical characteristics of the formulated tomato sauce for each variety after two weeks' elaboration are indicated in Table 2. The numbers comply with the United States standards for grades of tomato sauce under "U.S. Grade A" or U.S. Fancy" (1). This means that excellent tomato sauce can be produced in Puerto Rico with the locally grown varieties tested.

The following tabulation shows the microbiological content of each variety of canned tomato sauce. This evaluation was performed to verify the thermal process given to the formulated sauce before canning, which consisted of a one minute retention at $200^{\circ} \mathrm{F}\left(93^{\circ} \mathrm{C}\right)$ in a tubular heat exchanger. The microbiological results indicate that the varieties stored for a longer time [(Hybrid 337 and Ventura (o.p.)] before processing exhibited higher bacterial counts in the finished product. This was confirmed when the microbiological analyses of Hybrid 337 and Ventura (o.p.) sauces showed consistently higher bacterial counts than the ones of the other four sauces when assayed after a longer storage time.

\begin{tabular}{llc} 
Variety & \multicolumn{2}{c}{ Time } \\
Nema - 1 & 24 & Days \\
Nema - 2 & 48 & - \\
Zenith (hyb.) & 72 & - \\
Hybrid 337 & - & - \\
Ventura (o.p.) & - & 7 \\
Peto 98 (o.p.) & 24 & -
\end{tabular}


TABLE 1.-Mass balance per tomato variety

\begin{tabular}{|c|c|c|c|c|c|c|c|c|c|c|c|c|c|c|c|}
\hline Varieties & $\begin{array}{c}\text { (A) } \\
\text { Raw } \\
\text { material }\end{array}$ & $\begin{array}{c}\text { (B) } \\
\text { Selected } \\
\text { raw } \\
\text { material }\end{array}$ & $\mathrm{B} / \mathrm{A}$ & $\begin{array}{c}\text { (C) } \\
\text { Discarded } \\
\text { raw } \\
\text { material }\end{array}$ & $\mathrm{C} / \mathrm{A}$ & $\begin{array}{l}\text { Crushed } \\
\text { tomatoes }\end{array}$ & $\begin{array}{l}\text { Preheated } \\
\text { crushed } \\
\text { tomatoes }\end{array}$ & $\begin{array}{l}\text { Solids } \\
\text { after } \\
\text { pulper }\end{array}$ & Residue & $\begin{array}{l}\text { (D) } \\
\text { Solids } \\
\text { after } \\
\text { finisher }\end{array}$ & $\mathrm{D} / \mathrm{B}$ & Residue & $\begin{array}{c}\text { Tomato } \\
\text { concentrate }\end{array}$ & $\begin{array}{c}\text { Soluble } \\
\text { solids }\end{array}$ & $\begin{array}{c}\text { Evapmrated } \\
\text { water }\end{array}$ \\
\hline & lbsi & Ibs & st & Ibs & \% & lbs & lbs & lbs & lbs & Ibs & $\%$ & lbs & lbs & $\%$ & lbs \\
\hline Nema-1 & 192.60 & 180.70 & 93.82 & 11.90 & 6.18 & 179.70 & 169.82 & 161.50 & 8.32 & 1556.50 & 86.61 & 5.00 & 72.00 & 8.30 & 84.50 \\
\hline Nema- 2 & 189.75 & 175.25 & 92.36 & 14.50 & 7.64 & 174.25 & 164.66 & 161.00 & 3.66 & 154.75 & 88.30 & 6.25 & 76.00 & 8.40 & 78.75 \\
\hline Zenith (hyb.) & 188.00 & 166.00 & 88.30 & 22.00 & 11.70 & 165.00 & 154.75 & 148.00 & 6.75 & 141.50 & 85.24 & 6.50 & 76.75 & 7.50 & 64.74 \\
\hline Hybrid 33 ? & 191.75 & 142.00 & 74.05 & 49.75 & 25.95 & 139.00 & 131.00 & 125.50 & 5.50 & 120.75 & 85.04 & 4.75 & $55.00^{*}$ & 9.20 & 55.00 \\
\hline Ventura (o.p.) & 174.00 & 133.00 & 76.44 & 41.00 & 23.56 & 130.50 & 123.00 & 117.75 & 5.25 & 112.50 & 84.59 & 5.25 & $41.75^{*}$ & 10.00 & 66.50 \\
\hline Peto-98 (o.p.) & 167.50 & 163.00 & 97.31 & 4.50 & 2.69 & 161.50 & 153.00 & 146.010 & 7.00 & 138.00 & 84.66 & 8.00 & 62.25 & 8.00 & 75.75 \\
\hline
\end{tabular}

*Evaporator's losses, 10.75 and 4.25 , respectively. 
TABLE 2.-Physical and chemical characteristics of the formulated tomato sauce, for each variety, after 2 weeks of elaboration

\begin{tabular}{|c|c|c|c|c|c|c|c|c|c|c|}
\hline \multirow[b]{2}{*}{ Variety } & \multirow[b]{2}{*}{ Weight $(g)^{\prime}$} & \multirow[b]{2}{*}{ Vacuum (in. Hg) } & \multicolumn{4}{|c|}{ Total acidity } & \multirow{2}{*}{$\frac{\text { Refractive }}{\text { Index }}$} & \multicolumn{3}{|c|}{ Color } \\
\hline & & & ${ }^{\circ B}$ rix & $\mathrm{pH}$ & $\%$ & Viscosity (cm) & & L & a & $b$ \\
\hline Nema - 1 & 216.6 & 7.5 & 8.9 & 4.08 & .54 & 7.1 & 1.3462 & 26.41 & 22.46 & 13.27 \\
\hline Nema - 2 & 209.4 & 6.0 & 9.1 & 4.10 & .53 & 8.4 & 1.3463 & 26.49 & 23.02 & 13.25 \\
\hline Zenith (hyb.) & 208.0 & 9.0 & 8.8 & 4.07 & .54 & 6.9 & 1.3468 & 26.63 & 24.66 & 12.89 \\
\hline Hybrid 337 & 218.0 & 8.0 & 9.0 & 3.90 & .71 & 5.6 & 1.3462 & 26.38 & 26.39 & 12.40 \\
\hline Ventura (o.p.) & 212.6 & 9.0 & 10.0 & 4.18 & .62 & 5.8 & 1.3478 & 26.33 & 25.28 & 13.21 \\
\hline Peto 98 (o.p.) & 228.0 & 10.0 & 9.6 & 4.10 & .70 & 3.7 & 1.3473 & 28.33 & 25.93 & 14.92 \\
\hline
\end{tabular}

'Canned tomato sauce net weights and vacuum measurements.

Refractive index measured at $20^{\circ} \mathrm{C}\left(68^{\circ} \mathrm{F}\right)$. 
From the results obtained we can conclude that each of the tomato varieties used for sauce formulation is suitable for the purpose. It is worth mentioning that the soluble solids content in the fruits is an important parameter to consider, since a high solid to water ratio will reduce elaboration costs. A value of $4.5 \%$ falls within accepted ranges of initial soluble solid content in fresh tomatoes for processing (2).

\section{LITERATURE CITED}

1. Anonymous, 1987. "The Almanac of the Canning, Freezing, Preserving Industries," Edward E. Judge and Sons, Inc., Westminster, MD.

2. Bash, W. D., S. Z. Berry, and J. P. Dalmasso, 1987. Tomato cultivar evaluation; raw, canned and juice. Food Processing and Technology No. 292, Department of Horticulture, Ohio Agricultural Research and Development Center.

3. Binsted, R., J. D. Devey, and J. C. Dakin, 1962. "Pickle and Sauce Making." 2nd ed. London Food Trade Press LTD.

4. Bontovits, L., 1980. Colour measurements in tomato canning. Konserv-es Paprikaipar No. 4, 146-148. Abstract in FSTA Vol. 14 (1982) No. 9.

5. F.D.A., 1987. "Code of Federal Regulations-Food and Drugs 21, Parts 100-169." U.S. Government Printing Office, Washington, D. C.

6. Flynn, G. and P. C. Crowther, 1980. Tomato paste or puree: an industrial profile. Report, Tropical Products Institute G133, iv $+8 \mathrm{pp}$.

7. Goose, G., Peter and Binsted, Raymond, 1964. Tomato Paste, Puree, Juice and Powder. London Trade Press LTD.

8. Herschdoerfer, S. M., (Ed), 1986. "Quality Control in the Food Industry -Vol. 3." 2nd ed, Academic Press, London.

9. Lloyd, W. L. and W. A. Gould, 1987. Viscosity and lyophoresis of comminuted tomato products. Food Processing and Technology No. 292, Department of Horticulture, Ohio Agricultural Research and Development Center.

10. Rodrigo, M., 1984. La investigación actual en la industrialización del tomate. Rev. Agroquimica Tecnol. Alim. 24 (1): 1-14. 